\title{
THE OODA LOOP AS AN INSTRUMENT FOR DEVELOPING INTELLECTUAL PROPERTY STRATEGIES IN SMES
}

\begin{abstract}
Intellectual property is closely related to the processes of creation and to the development and use of acquired knowledge, experience, and competence. It is also the result of human creativity, creativity, entrepreneurial behaviour, ideas, and inventions. The dynamics of the business environment, which should be considered both in macro- and micro-economic terms, forces companies to strive for continuous modification and diversification of economic and financial strategies. This same principle also applies to intellectual property strategies, which can be used not only in creating wealth but also in attaining competitive advantage for an enterprise. This article proposes the creation of intellectual property strategy based on the OODA loop, a model of a continuous process under continuous observation. All decisionmaking processes usually take place parallel to one another. The essence of the model is synchronization between observation and orientation; between orientation, decision and action; and the impact of actions taken by observation are assumed to be monitored. Basing creation of an intellectual property strategy on the OODA loop as proposed here is recommended for SMEs in Poland.
\end{abstract}

Keywords: enterprise, strategy, creative strategy, intellectual property, OODA loop.

\section{INTRODUCTION}

Intellectual property is a concept that refers to unique, value-creating creations of human creative and creative expression. From a legislative point of view, we are talking about a certain category of goods created through an intellectual process, which have been incorporated in a material form and are protected. In other words, intellectual property is a set of rights resulting from human activity, especially in the literary, artistic, scientific and industrial fields. These rights include: patents, protection rights covering utility models, industrial designs, trademarks, geographical indications, topography of integrated circuits (industrial property), copyrights and related rights and know-how (confidential technical, technological, economic, organizational information). Obtaining intellectual property rights means granting the person or persons entitled exclusive rights whose duration may be unlimited (rights inalienable in copyright, right of protection for a geographical indication), or which may be limited in time (invention patent, right of protection for a utility model,

\footnotetext{
${ }^{1}$ Aldona Małgorzata Dereń, DSc, PhD, Associate Prof., Faculty of Computer Science and Management, Wroclaw University of Science And Technology, Poland; e-mail: aldona.deren@pwr. edu.pl. ORCID: 0000-0002-2377-4573.
} 
right of protection for a trademark, right of registration for a design, right of registration for an integrated circuit topography). In any case, substantive exclusive rights are territorially limited, for example to the territory of a country, group of countries, geographical region. On the other hand, intangible rights are not limited in time and space (the author of the work is everywhere and remains forever). By obtaining a material exclusive right, the right holder acquires the right to use the object of protection exclusively for profit or professional purposes (monopoly) in the territory to which the right applies. The limitation in time of the monopoly for categories of intellectual property related to technical innovation is intended to allow competition and dissemination. The formal granting of property rights to creative human work has allowed to exploit the commercial value of human ingenuity and creativity. The results of creative work have become a resource that can be used to exchange or share rights with different types of business partners in a complex network of strategic relationships. This allows the creation and marketing of new and improved goods and services on more than just a single market.

In recent years, intellectual property has become a key resource in almost all sectors of the global economy. In short, intellectual property is becoming increasingly strategic. The growing importance of these "resources of the mind" raises questions about how best to use them to achieve the goals of the companies that create and control them. In this situation, it becomes necessary for organizations to develop strategies that exploit and maximize the value of their intellectual property assets.

The aim of this study is to describe the issues of developing an effective intellectual property strategy in relation to SMEs in Poland. The resultant aim of the article is to describe the course of the process of formulating this strategy using the OODA loop developed by military strategist Colonel John Boyd (https://pl.wikipedia.org/wiki/OODA, 2020).

\section{INTELLECTUAL PROPERTY STRATEGY}

As already mentioned, intellectual property is closely related to the processes of creation, development and use of acquired knowledge, experience and competence and is the result of human creativity, creativity, entrepreneurial behaviour, ideas and invention. Intellectual property is distinguished by the fact that its economic value can be determined and it is subject to legal protection (Blair, Cotter, 2005).

The perception of intellectual property as a resource with specific characteristics (attributes) allows to show its specific character, which is often difficult to understand from the point of view of tradition, supported by established rules and standards of treating material resources as a fundamental basis for management. And such attitudes dominate in small and medium enterprises.

Meanwhile, the features (properties) of intellectual property, and above all its close connection with man, allow for differentiation and specificity of shaping intellectual property as a resource (Dereń, 2014). The most important of these characteristics are: independence, incalculability, indivisibility, usefulness, ability to protect and ability to commercialize. This is a feature of bringing intellectual property to a form that allows it to sell on the market and compete. This ability is dynamic, variable and dependent on many factors. It is aimed at absorbing intellectual knowledge and creative skills in the production process to successfully market them as product(s). Y. S. Rajan (2002) defines commercialisation as "creating added value for ideas, research results, technology and new product". A feature of intellectual property is also strategicity. In the most general terms, 
the strategicity of the resource is to ensure the survival and development of the company, which should be reflected in the change of strategic position in the sector. The resourcebased strategy should therefore take into account all the intangible resources of the organisation that are conducive to achieving the strategic objectives. Nowadays, intellectual property and the ability of an organisation to multiply and protect it play a key role in the collection of intangible resources that determine the success of an enterprise.

The strategy of intellectual property may vary depending on the size of the organisation. Large companies with significant financial resources often seek a strategy based on acquiring and maintaining a large number of patents (patent portfolio). However, for most start-ups or SMEs, developing and building a large patent pool can be disproportionately costly.

Any discussion of an intellectual property strategy must be considered as part of the organisation's strategy. It is therefore necessary to define the objectives of this strategy. It is quite common to refer to 'achieving sustainable competitive advantage' as a goal, sometimes 'sustainability' is mentioned. In other words, the organisation's strategy is to develop a range of activities that will allow the company to generate a sustainable profit stream. An effective strategy will allow the company to achieve sustainable profits, which are higher than those of its competitors.

The basic profit formula:

$$
\pi=(\mathrm{P} \text { X Q })-\mathrm{C}
$$

And yes: Profit $(\pi)$ is income (Price times quantity) minus Costs.

Thus, the organisation's strategy is to develop a range of activities that will enable the company to sustainably achieve higher prices than its competitors $(\mathrm{P})$, increase its market share (Q) and/or maintain lower costs (C) than its competitors. As part of the organisation's strategy, the intellectual property strategy must pursue the same objectives. It must make a significant contribution to the company's profit generation. Therefore, an IP strategy consists of developing a range of activities using IP to enable the company to sustainably achieve higher prices, increase market share and/or maintain lower costs than its competitors.

An intellectual property strategy can contribute to a company's profitability by enabling it to maintain and increase its market share. As a rule, after making a choice, customers choose products that provide a combination of price, features and performance that meets their needs. Companies that are able to differentiate their products in a way that benefits their customers and is difficult or impossible for competitors to replicate are likely to gain disproportionate market share. One example is Gillette, which has maintained more than $70 \%$ market share of razor blades thanks to continuous innovation, patent protection and investment in branding. Apple iPhone and iPad products hold 30\% and 50\% of the US smartphone and tablet market respectively. And Apple is very aggressive in enforcing its intellectual property rights to maintain its leading position in features it considers important for consumers. It also maintains a strong and continuous branding campaign to strengthen its market position.

An intellectual property strategy can contribute to a company's profitability by helping to keep costs lower than those of its competitors. This can be achieved in two main ways. First, companies can achieve lower costs through production or service technologies that 
are protected from competition by intellectual property. In some cases it is appropriate to protect trade secrets, while in others patent protection is the best strategy.

In many industries, competition is based on cost minimisation, especially in commodity industries where the product is relatively undifferentiated from that of the competitor. In these circumstances, product performance, functions and brand are usually less important when customers make purchasing decisions. Consequently, there is no justification for higher prices and attempts to do so directly lead to a loss of market share. In these industries, anyone with a cheap production or service system will have the highest profit margins. The low cost producer is free to lower its price and take over market share. Proper application of an intellectual property strategy can help companies to achieve a sustainable cost advantage and directly contribute to the profitability of the organisation.

An intellectual property strategy can also be an effective tool in achieving lower technology costs than competitors. In many markets, the cost of technology is a significant and growing part of the total cost of goods sold. In markets with complex technology, companies' products include solutions and technologies developed at home and licensed. In such cases companies are forced to trade in technology in order to bring their product to market. Access to the required technology is obtained through licensing agreements and reciprocal agreements. In some industries, such as consumer electronics, the total cost of access to technology (including patent royalties) can represent 20-30\% of the sales price of the product and in some product categories, such as smartphones, can be even higher. Companies that are able to achieve the lowest "technology cost" through a favourable royalty balance can maintain higher profit margins than their competitors (Deren, Skonieczny, 2017). The balance of technology payments covers not only the cost of accessing a competitor's technology, but also technology owned by non-manufacturing entities. Companies that effectively manage their licences can also maintain higher margins and profits.

The considerations set out above referred to the objectives of the intellectual property strategy. The key question is what is the nature of the strategy and how to develop it? What is the way to choose to make the strategy achieve its objectives and contribute to the competitiveness of the company and its sustainable profitability?

The strategy of intellectual property is creative because, as J. Skonieczny (2019) notes, every strategy of an organization, regardless of its conditions, method of development and methods used, is always creative.

Similarly, R.S. Kaplan and D. P. Norton (2010) speak about the role of creativity in the organization's strategy. P. Norton believe that:

whatever methodology is adopted, the result of formulating a strategy is to establish a course of action that distinguishes the company's position and offer from its competitors, so that it can achieve a lasting competitive advantage leading to first-class financial results...

W. Dyduch (2013) writes that the creative strategy is future-oriented and goal-oriented, leaving room for discovering the individual potential of the participant in the organisation and unplanned paths and ways to achieve organisational goals. The creative nature of the intellectual property strategy makes its creation a process of searching for and combining various solutions to achieve specific organizational goals. As W. Dyduch writes, a creative strategy can be seen as taking steps outside the established framework and as an invitation 
to adopt a more eclectic approach to a product, organisation, or sector, and to constantly switch between different strategic approaches.

The creative nature of intellectual property means that it is open to a variety of organisational cultures, especially those where even the edges of ideas and values are born. This strategy is not about creating simple, stuntless solutions that could be used in the organisation in the long term.

Developing a creative intellectual property strategy is a process of learning from mistakes combined with enthusiasm for new ideas. The profile of this strategy is based on the multiplicity and diversity of opinions and views. It is not possible to create this strategy on the basis of standard schemes, as this excludes the specificity and characteristics of intellectual property treated as an intangible asset of the organization. This strategy cannot be developed in the traditional way, which originated from the ancient army leadership, the scheme of analysis, planning and rigid implementation of decisions made. Even on the day after carefully planned decisions are made, the external environment of the company may be completely different. In the author's opinion, the intellectual property strategy is first of all a way of thinking, a way of observing the environment inside and outside the organization, giving meaning to the collected information and acquired knowledge, is a kind of wisdom of the organization.

In order to answer the question of how to create such a strategy, what actions to choose in order for this strategy to contribute to the company's competitiveness and sustainable profitability, it is necessary to start with the organization's strategy. Unfortunately, in many small and medium sized national enterprises it simply does not exist or is in a very general form. On the other hand, what is (or should be) the developed strategy of the enterprise is crucial for defining the profile of intellectual property strategy.

It is not easy to define what an enterprise's strategy is, especially if one sets out the enterprise's business activity in a broad social context, or if one introduces many factors that are difficult to define and predict precisely (Kasprzycki at al, 2008). In the literature on the subject, the enterprise's strategy is most often defined as the entirety of actions taken by its management to set the main objectives, formulate a general concept of functioning and define the ways and means of action to achieve these objectives.

It can also be said in the most general sense that the strategy is to ensure the survival and development of the company, which should be reflected in a change of position in the sector. The strategy should therefore take into account all the factors that favour and hinder the achievement of the objectives. Nowadays, in the set of factors determining a company's success, a key role is played by its intellectual potential, its ability to expand and protect it. In other words, intellectual resources nowadays determine the market position of a company in the sector.

The complexity and specificity of intellectual property, the various connections and organisational conditions of a company, its industry, institutional and market location, as well as existing relations with the competitive environment have a significant impact on modelling intellectual property strategies.

The intellectual property strategy also depends on the size of the organisation. It is different in large companies with significant financial resources, and different in small and medium-sized enterprises with limited resources. 


\section{OODA LOOP}

The OODA (Observe-Orient-Decide-Act Observation-Orient-Decide-Act) is a model of the adaptive decision making cycle developed by military strategist Colonel John Boyd at the turn of 1970-1980. This model was adopted in the doctrine of the US military. Its essence consists of four basic areas of information processing, which are observation, orientation, decisions and actions.

Observation - consists in collecting data on various aspects of the environment in which the organization operates. One of the key streams of observation is observation of feedback related to decisions and actions taken.

Orientation - is overlaying the collected information on the current conceptual model describing the environment and synthesizing the premises (stimuli) for making decisions and actions. The process of orientation is fundamental to the effectiveness with which the whole OODA cycle is implemented. Cultural conditions (organizational culture of the company), innate features, experience and routine of employees have an impact on the speed and precision of actions, as well as on reacting to changes taking place. The ability to analyze and synthesize allows to consciously change conceptual models used by people in the assessment of the situation and to act effectively even where reflexes and experience do not reach.

Decisions - in the case of decisions taken deliberately and non-routineously, there is a choice/rejection of one of the options for action. Decisions can also be reflexes, in which case the action is (or is rejected) "automatic".

Action - it is undertaking (consciously or reflexively) the realization of one of the previously worked out scenarios. When starting to interact with the environment, the decision itself is, in a way, tested in practice (providing additional data and premises). The conceptual model which is the basis of orientation is also tested. The action allows to learn and adopt to a variable and not fully understood environment.

The information processing in all four of these areas is in principle parallel. According to the creator of the OODA concept, the essence of the loop is the synchronization between observation and orientation; between orientation, decision and action; and finally, the monitoring of the impact of actions taken through observation. J. Boyd himself presents it in his briefing "The Essence of Winning and Loosing" as follows:

Pay attention to how orientation influences observation, decisions and actions, on the other hand it is itself shaped by feedback and other phenomena appearing in our area of observation. Also, pay attention to how the whole loop (not only orientation) creates a continuous, multi-faceted, interconnected process of anticipating, sensing, correlating and rejecting ${ }^{2}$.

The fundamental strategy related to the practical application of the OODA loop in warfare consisted in the creation of mechanisms allowing for the use of key factors such as: pilots' training, innate abilities of each of them and the fighters they used. F86 jets, on which

2 J. Boyd did not leave any written material behind. He was a practitioner and popularized his concepts and ideas mainly through his briefings, such as: Patterns of Conflicts or The Essence of Winning and Loosing. Towards the end of his life, he published a 12-page essay from Zt. Destruction and Creation. It is a work devoted to the process of creating and disintegrating conceptual models in the process of learning and shaping reality. Cf. [Access: 15.04.2020]. Access on the internet: https://pl.wikipedia.org/wiki/John_Boyd_(1927\%E2\%80\%931997). 
American pilots flew, provided much better visibility from the cockpit than MIG and 15 opponents. They were much more agile at higher speeds. Therefore, J. Boyd claimed that the technical advantages of the equipment combined with the skills of a handful of pilots meant that the best of them could react much faster to the enemy's maneuvers, causing confusion and inappropriate reactions during combat, which ultimately led to loss of control over the situation. As J. Boyd noted (https://pl.wikipedia.org/wiki/OODA, 2020).

Flying on fighters and running a business are different and incomparable activities, but the OODA loop (model) has gained popularity as a helpful tool to understand today's uncertain and turbulent business environment. The OODA series, although developed by the fighter pilot, is, according to Steve Blank, the basis for concepts such as Customer Development and Lean Startup (product management in uncertain conditions). Observation-Orientation-Decision-Action is also a model of strategic thinking in modern, highly competitive business (Blank, Dorf, 2013).

Can such a pattern of thinking be applied to intellectual property, which is an important component of building competitiveness and market advantage. It is an attribute of a modern economy, and uncertainty about the possibility of obtaining and enforcing protection of rights exposes entrepreneurs and the whole economy to significant losses. This issue is particularly relevant for SMEs. Research conducted by the author in the SME sector in 2015 and 2019 indicate that the knowledge and awareness of the importance of these resources is so low that it limits the development perspective of most of these enterprises as innovative organisations. This weakness may be prevented by developing an intellectual property strategy based on the OODA loop.

\section{DEVELOPING AN INTELLECTUAL PROPERTY STRATEGY BASED ON THE OODA LOOP}

The creative nature of the intellectual property strategy means that its development is not a one-off or periodic action, but a continuous decision-making process. The creativity itself is a two-dimensional process consisting of search-and-research and diagnosticanalytical elements (Skonieczny, 2019). The creative potential of a company, its employees and its material and non-material resources have an impact on the shape of the organisation's strategy and its component, which is the intellectual property strategy. This is very accurately illustrated by the description of the strategy developed by J. Boyd and called the OODA loop. The strategy observes what is happening in the environment (inside and outside the organisation), orientates itself in situations, collects facts and analyses circumstances of their creation. Only then he decides on the way of action and makes appropriate decisions. The results of these actions are then observed and the strategist goes through the OODA loop again.

The concept of the OODA loop translates directly into a continuous process of developing an intellectual property strategy in the following diagram:

Observation - the development of an intellectual property strategy starts with a thorough analysis of the internal and external environment. The analysis of the environment within an organisation is primarily a clear indication of what constitutes added value for the company (e.g. specific software, distinctive product name etc.). Further, determining the amount of intellectual resources at the disposal of companies (both own and purchased or licensed solutions, devices, etc. are taken into account). 
An analysis of the environment within an organization is also a determination of what is planned to be created as a result of creative work. It will allow to indicate in which direction the company will develop.

Internal observation requires the monitoring of an organisation's performance in the field of intellectual property creation, including obtaining information on R\&D results and innovation activities undertaken.

Knowledge of what is happening in the external environment includes querying information about the technological environment, customer needs, competitors' activities, partner's ecosystem and legal environment. The search for information about existing technological solutions is made possible by Internet databases containing data about existing and submitted solutions. It is also reasonable to use patent literature, as it not only assesses the protective capacity of innovations, but also prevents the duplication of research results (balancing open doors) and provides information about the intellectual potential of competition. In the case of small and medium-sized enterprises, it can be recommended to use a professional advisor - a patent attorney.

Orientation - this is a process of analysing and filtering relevant and up-to-date information among people in the organisation who need to know it. Choosing which information is most important, who needs it and who is able to make the best use of it is crucial for preparing the staff implementing the intellectual property strategy.

Decision - understanding and analysis of processes taking place inside and outside the organization allows to design decisions concerning the way the organization operates with respect to intellectual property. Decision making is at the heart of the IP strategy, and must be aligned with the overall strategy established by the organisation. The outcome of the decision-making process may be a formal or informal strategic plan that should at least set out the priorities and objectives for the organization's activities with respect to intellectual property.

Action - The actions taken to implement the Intellectual Property Strategy start already at the stage of creating innovations protected by intellectual property rights, through the creation of intellectual property resources, and further on the choice of formal mechanisms for the protection of intellectual property. These activities culminate in the introduction and use of these resources on the market. These activities can focus on product development and customer location, which will allow the company to achieve higher margins. A unique technological solution can be obtained through own research, purchased or licensed from another entity. On the other hand, having a patent monopoly allows you to become a leader controlling the market, and a deliberate pricing policy gives you a chance to achieve high margins.

\section{SUMMARY}

Intellectual property is the entirety of the creations of the human mind, the results of creative work, talent, imagination, creativity and inventiveness, and specific expenditures (time, financial and material capital, current state of the art). When these products are created in an organization, they are used as intangible resources in the production of subsequent goods and services. As Roger D. Blair and T.F. Cotter (2005), intellectual property is distinguished by the fact that its economic value can be determined and it is protected by law. When knowledge resources become subject to intellectual property rights, 
it is possible to derive financial benefits from the distribution and use of those resources sale, transfer, commercialisation.

The dynamics of the business environment, which should be considered both in macroand micro-economic terms, forces companies to strive for continuous modification and diversification of economic and financial strategies. This also applies to the intellectual property strategy, which can not only be "(...), (...) used to create wealth, but most of all the competitive advantage of the enterprise" (Nogalski, Rybnicki, 2001).

Despite the lack of access to capital, lack of experience and rather low level of economic knowledge of entrepreneurs and often lack of development strategy, small and mediumsized enterprises are characterized by a dynamic transition to the environment. It is generally believed that these organisations are able to react fastest to changing needs and preferences of potential customers. They have an accurate understanding of the market situation and therefore are more easily involved in specific investment projects. For large entities, operating on small markets may not be profitable, hence they often give way to small or medium-sized companies. However, in order for them to operate in niche markets and markets with smaller potential, they must have not only an overall strategy, but also an intellectual property strategy, which is its component. The creation of this strategy can be based on the OODA loop. This model is a continuous process and operates on a continuous observation basis. All decision making processes usually take place parallel to each other. The essence of the model is the synchronization between observation and orientation, between orientation, decision and action, and monitoring the impact of actions taken by observation.

\section{REFERENCES}

Blair, R. D., Cotter T. F. (2005). Intellectual Property Economic and legal Dimensions of Rights and Remedies. Cambrigde University Press.

Blank, S., Dorf, B., Podręcznik startupu. Budowa wielkiej firmy krok po kroku. Warszawa: Wyd. Onepress.

Dereń, A. M. (2014). Zarzadzanie własnościa intelektualna w transferze technologii. Warszawa.

Dereń, A. M., Skonieczny, J. (2017). Cykl rozwoju przedsiębiorczości intelektualnej organizacji - zarys problemu [w:] Balcerak, A., Malary, Z., red. Innowacyjność w gospodarce, organizacji i technice. Warszawa.

Dyduch, W. (2013). Twórcza strategia - przemijająca koncepcja, czy przyszłość zarządzania strategicznego? „Zarzadzanie strategiczne, Quo vadis?, praca zbior. pod red. R. Krupskiego. Prace Naukowe Wałbrzyskiej Wyższej Szkoły Zarządzania i Przedsiębiorczości. T. 22(2). Wydawnictwo Wałbrzyskiej Wyższej Szkoły Zarządzania i Przedsiębiorczości w Wałbrzychu. Access on the internet: http://www.pracenaukowe.wwszip.pl/prace/pracenaukowe-22.pdf

https://pl.wikipedia.org/wiki/OODA [Access: 15.04.2020].

Kaplan, R. S., Norton, D.P. (2010). Wdrażanie strategii dla osiagnięcia przewagi konkurencyjnej. Warszawa: Wydawnictwa Profesjonalne PWN.

Kasprzycki, D., Matczewski, A., Okoń-Horodyńska, E., du Vall, M., Wisła R. (2008). Zarzadzanie własnościa intelektualna $w$ przedsiębiorstwie - regulaminy korzystania $z$ wyników prac intelektualnych powstatych $w$ przedsiębiorstwie. Kraków. 
Nogalski, B., Rybnicki, J. (2001). Zarzadzanie portfelem kapitału intelektualnego [w:] Kapitat intelektualny. Dylematy i wyzwania. Nowy Sącz: Wyższa Szkoła Biznesu - National-Louis University.

Rajan, Y. S. (2002). Empowering Indians. With economic, business and technology strengths for the twenty first century. New Delhi: Har Anand Publications.

Skonieczny, J. (2019). Twórczość jako fundament strategii organizacji. Wrocław: Oficyna Wydawnicza Politechniki Wrocławskiej.

DOI: 10.7862/rz.2021.hss.11

The text was submitted to the editorial office: May 2020.

The text was accepted for publication: June 2021. 